\title{
ANALISIS KEMAMPUAN LITERASI SAINS DITINJAU DARI KEBIASAAN MEMBACA, MOTIVASI BELAJAR DAN PRESTASI BELAJAR
}

\author{
Rosmalah Yanti ${ }^{1}$, Titi Prihatin ${ }^{2}$ dan Khumaedi ${ }^{3}$ \\ ${ }^{1}$ Pendidikan Guru Sekolah Dasar, Fakultas Keguruan dan Ilmu Pendidikan, Universitas Cokroaminoto Palopo, Palopo, \\ 91921, Indonesia \\ ${ }^{2}$ Teknologi Pendidikan, Fakultas Ilmu Pendidikan, Universitas Negeri Semarang, Semarang, 50229, Indonesia \\ ${ }^{3}$ Fisika, Fakultas Matematika dan Ilmu Pengetahuan Alam, Universitas Negeri Semarang, Semarang, 50229, Indonesia \\ Email: rosmalahy@gmail.com
}

Diajukan: 1 Agustus 2020; Diterima: 2 September 2020; Diterbitkan: 30 Oktober 2020

\begin{abstract}
Abstrak: Penelitian ini bertujuan untuk menganalisis (1) pengaruh langsung kebiasaan membaca terhadap motivasi belajar; (2) pengaruh langsung kebiasaan membaca terhadap prestasi belajar; (3) pengaruh langsung motivasi belajar terhadap prestasi belajar; (4) pengaruh langsung kebiasaan membaca terhadap kemampuan literasi sains; (5) pengaruh langsung motivasi belajar terhadap kemampuan literasi sains; (6) pengaruh langsung prestasi belajar terhadap kemampuan literasi sains; (7) pengaruh tidak langsung kebiasaan membaca terhadap prestasi belajar; (8) pengaruh tidak langsung kebiasaan membaca terhadap kemampuan literasi sains; dan (9) pengaruh tidak langsung motivasi belajar terhadap kemampuan literasi sains. Metode penelitian ini adalah Ex Post Facto. Sampel berjumlah 112 siswa kelas VII di Kabupaten Luwu. Pengambilan sampel menggunakan cluster random sampling. Teknik analisis data menggunakan analisis jalur. Hasil penelitian adalah sebagai berikut 1) kebiasaan membaca berpengaruh secara langsung sebesar $0,16 \%$ terhadap motivasi belajar, $9,67 \%$ terhadap prestasi belajar, dan 3,6\% terhadap kemampuan literasi sains; 2) motivasi belajar dapat memberikan pengaruh langsung sebesar $1,58 \%$ terhadap prestasi belajar, dan 3) prestasi belajar memberi pengaruh langsung terhadap kemampuan literasi sains sebesar 7,12\%. Pengaruh tidak langsung kebiasaan membaca sebesar 10,17\% terhadap prestasi belajar melalui motivasi belajar, serta berpengaruh terhadap kemampuan literasi sains melalui motivasi belajar sebesar 3,73\%. Motivasi belajar tidak berpengaruh terhadap kemampuan literasi sains siswa. Kemampuan literasi sains siswa secara dominan dipengaruhi oleh kebiasaan membaca sehingga sebaiknya siswa dilatih dan dibiasakan mengerjakan soal-soal yang menguji dan dapat meningkatkan kemampuan literasi sains..
\end{abstract}

Kata Kunci: Literasi Sains, Kebiasaan Membaca, Motivasi belajar, Prestasi Belajar

Abstract: This study aims to analyze (1) the direct influence of reading habits on learning motivation; (2) direct influence of reading habits on learning achievement; (3) the direct influence of learning motivation on learning achievement; (4) direct influence of reading habits on scientific literacy skills; (5) the direct effect of learning motivation on scientific literacy ability; (6) direct influence of learning achievement on scientific literacy ability; (7) the indirect effect of reading habits on learning achievement; (8) the indirect effect of reading habits on scientific literacy skills; and (9) the indirect effect of learning motivation on scientific literacy ability. This research method is Ex Post Facto. The sample is 112 class VII students in Luwu Regency. Sampling used cluster random sampling. The data analysis technique used path analysis. The results of the study are as follows: 1) reading habits have a direct effect of $0.16 \%$ on learning motivation, $9.67 \%$ on learning achievement, and $3.6 \%$ on scientific literacy skills; 2) learning motivation can have a direct effect of $1.58 \%$ on learning achievement, and 3) learning achievement has a direct influence on scientific literacy skills of $7.12 \%$. The indirect effect of reading habits is $10.17 \%$ on learning achievement through learning motivation, and the effect on scientific literacy skills through learning motivation is 3.73\%. Learning motivation has no effect on students' scientific literacy skills. Students' scientific literacy ability is dominantly influenced by reading habits so that students should be trained and accustomed to working on questions that test and can improve scientific literacy skills.

Keywords: Science Literacy, Reading Habits, Learning Motivation, Learning Achievement

\section{Pendahuluan}

Indonesia telah menjadi partisipan PISA (Programme for International Student
Assessment) sejak tahun 2000, namun hasil yang diperoleh masih perlu untuk ditingkatkan. Hasil penelitian PISA tahun 2015 telah dirilis oleh Kemendikbud (2016) yang menunjukkan 
kenaikan pencapaian pendidikan di Indonesia yang signifikan yaitu sebesar 22,1 poin. Hasil tersebut menempatkan Indonesia pada posisi ke empat dalam hal kenaikan pencapaian siswa dibanding hasil survei sebelumnya pada tahun 2012 dari 72 negara yang mengikuti tes PISA. Berdasar nilai median capaian literasi siswa Indonesia dapat terlihat dalam Tabel 1.

\begin{tabular}{cccc}
\multicolumn{4}{c}{ Tabel 1. Capaian Literasi Siswa Indonesia } \\
\hline \multirow{2}{*}{ No } & \multirow{2}{*}{ Aspek Literasi } & 2012 & Tahun \\
\cline { 3 - 4 } 1 & & 337 & 350 \\
2 & Membaca & 318 & 335 \\
3 & Matematika & 327 & 359 \\
\hline
\end{tabular}

Secara konsisten terjadi peningkatan cakupan sampling siswa Indonesia yaitu sebanyak 46 persen di tahun 2013 menjadi 53 persen di tahun 2006, angka tersebut naik ke 63,4 persen di tahun 2012 dan menjadi 68,2 persen di tahun 2015. Dari hasil survey siswasiswa Indonesia yang bersekolah di sekolah negeri mencatat nilai 16 poin lebih tinggi di bidang kompetensi sains, dibandingkan siswa yang bersekolah di sekolah swasta, dengan mempertimbangkan latar belakang status sosial ekonomi.

Permanasari, 2014 mengungkapkan bahwa kemampuan literasi sains, matematika dan membaca saling memiliki keterkaitan. Kelemahan umum yang diperoleh dari hasil analisis bahwa anak-anak Indonesia kesulitan memaknai bacaan dan memberikan evaluasi kritis terhadap suatu bacaan.

Motivasi sangat berperan penting dalam meningkatkan prestasi belajar siswa karena pentingnya pengaruh motivasi terhadap prestasi, sehingga siswa harus dapat menumbuhkan dan mengembangkan motivasi belajar yang ada didalam dirinya (Rafiqah dkk, 2013).

Permasalahan tentang rendahnya kemampuan literasi sains secara umum yang dialami oleh siswa di Indonesia, juga dialami oleh siswa di SMP Negeri 2 Bua Ponrang, hal ini terlihat saat dilakukan uji coba dan penelitian hampir seluruh siswa tidak mampu untuk mengerjakan soal kemampuan literasi sains yang diberikan sehingga dapat disimpulkan bahwa siswa masih belum terbiasa untuk mengerjakan soal-soal yang berkaitan dengan literasi utamanya literasi sains.

Kurangnya pengetahuan siswa dengan istilah literasi sains, guru mengajar dengan tujuan agar siswa memperoleh nilai sesuai dengan kriteria ketuntasan minimal sehingga ketika siswa diberi soal untuk mengukur kemampuan literasi sains tidak ada siswa yang mampu mencapai nilai sesuai dengan kriteria ketuntasan minimal.

Minimnya data yang ditemukan tentang kemampuan literasi sains untuk siswa di Kabupaten Luwu terkhusus di SMP Negeri 2 Bua Ponrang mengindikasikan bahwa pihakpihak yang terkait belum tertarik untuk melakukan penelitian tentang kemampuan literasi sains yang dimiliki oleh siswa

Berdasarkan hasil pemaparan di atas sehingga perlu untuk dilakukan penelitian tentang kemampuan literasi sains khususnya di SMP Negeri 2 Bua Ponrang yang telah dibiasakan membaca serta memiliki motivasi dan prestasi belajar yang baik.

Penelitian ini bertujuan untuk menggambarkan pengaruh langsung kebiasaan membaca terhadap motivasi belajar, pengaruh langsung kebiasaan membaca terhadap prestasi belajar, pengaruh langsng motivasi belajar terhadap prestasi belajar, pengaruh langsung kebiasaan membaca terhadap kemampuan literasi sains, pengaruh langsung motivasi belajar terhadap kemampuan literasi sains, pengaruh langsung prestasi belajar terhadap kemampuan literasi sains, pengaruh tidak langsung kebiasaan membaca terhadap prestasi belajar dan pengaruh tidak langsung kebiasaan membaca terhadap kemampuan literasi sains.

\section{Metode Penelitian}

Penelitian ini adalah penelitian Ex Post Facto dengan teknik analisis jalur (path analysis). Penelitian analisis jalur memiliki dua variabel yaitu variabel endogen dan eksogen. Variabel eksogen adalah kebiasaan membaca, motivasi belajar, dan prestasi belajar, serta literasi sains sebagai variabel endogen.

Populasi penelitian ini adalah seluruh siswa kelas VII SMP Negeri 2 Bua Ponrang dengan teknik pengambilan sampel yaitu simple random sampling dengan jumlah 112 siswa. Teknik pengumpulan data yang digunakan dalam penelitian ini adalah kuisioner kebiasaan membaca dan motivasi belajar dan teknik tes dengan instrumen berupa soal tes literasi sains. 


\section{Uji Persyaratan Analisis}

\section{Uji Normalitas}

Uji normalitas data dilakukan untuk mengetahui bahwa sampel populasi yang digunakan adalah berdistribusi normal (Sandjojo 2014:90). Uji normalitas menggunakan uji Liliefors yaitu antara variabel $\mathrm{X}_{1}$ (kebiasaan membaca) terhadap $\mathrm{Y}$ (literasi sains) , $\mathrm{X}_{2}$ (motivasi belajar) terhadap $\mathrm{Y}$ (literasi sains), serta $X_{3}$ (prestasi belajar) terhadap Y (literasi sains). Normalitas variabel dinyatakan dengan nilai $p$-value dari hasil perhitungan SPSS Statistic 20, jika nilai signifikansi yang diperoleh $>0,05$ maka sampel berdistribusi normal. Variabel Y (kemampuan literasi sains) atas $\mathrm{X}_{1}$ (kebiasaan membaca) didapatkan nilai sebesar 0,172, Y (kemampuan literasi sains) atas $\mathrm{X}_{2}$ (motivasi belajar) sebesar 0,165 , serta $Y$ (kemampuan literasi sains) atas $\mathrm{X}_{3}$ (prestasi belajar) sebesar 0,200. Nilai $p$ value yang lebih besar dibandingkan 0,05 dapat diartikan bahwa kemampuan literasi sains berditribusi normal atas kebiasaan membaca, motivasi belajar, dan prestasi belajar.

\section{Uji Homogenitas}

Uji homogenitas dengan uji One Way ANOVA. Tiap variabel dikatakan homogen jika nilai signifikansi yang diperoleh $>0,05$ maka sampel berdistribusi normal karena $p$-value > 0,05 . Hasil uji homogenitas yang diperoleh yaitu variabel $\mathrm{Y}$ (kemampuan literasi sains) dengan $\left(\mathrm{X}_{1}\right)$ kebiasaan membaca diperoleh sebesar 0,316, variabel Y (kemampuan literasi sains) dengan $\left(\mathrm{X}_{2}\right)$ motivasi belajar diperoleh sebesar 0,299 yang berarti, dan variabel $Y$ (kemampuan literasi sains) dengan $\left(\mathrm{X}_{3}\right)$ prestasi belajar diperoleh sebesar 0,942 sehingga dapat dikatakan bahwa setiap data mempunyai varians yang sama.

\section{Uji Linieritas}

Uji ini dimaksudkan untuk mengetahui bahwa variabel-variabel yang dirumuskan dalam model teoritik penelitian mempunyai hubungan linear secara nyata (Sandjojo, 2011:91). Linieritas digunakan untuk mengetahui apakah hubungan antara masingmasing variabel eksogen dan variabel endogen bersifat linier. Setiap variabel dikatakan mempunyahi hubungan yang linier jika signifikansi yang diperoleh $>0,05$. Nilai $p$ - value yang lebih besar dibandingkan 0,05 dapat diartikan bahwa kemampuan literasi sains linier atas kebiasaan membaca, motivasi belajar, dan prestasi belajar. Variabel Y (kemampuan literasi sains) atas $\mathrm{X}_{1}$ (kebiasaan membaca) didapatkan nilai sebesar 0,146, Y (kemampuan literasi sains) atas $\mathrm{X}_{2}$ (motivasi belajar) sebesar 0,954 , serta $Y$ (kemampuan literasi sains) atas $\mathrm{X}_{3}$ (prestasi belajar) sebesar 0,387.

\section{Teknik Analisis Data}

Teknik analisis data menggunakan cara deskriptif dan inferensial. Teknik analisis deskriptif digunakan untuk menggambarkan kebiasaan membaca, motivasi belajar, prestasi belajar dan kemampuan literasi sains.

Analisis inferensial digunakan untuk melakukan uji hipotesis setelah uji persyaratan analisis terpenuhi. Uji hipotesis meliputi perhitungan koefisien jalur, perhitungan pengaruh langsung dan tidak langsung antar variabel, dan pengujian kecocokan model (model fit). Koefisien jalur dihitung menggunakan bantuan program SPSS Statistic 20. Setelah koefisien jalur diketahui, maka dapat dihitung pengaruh langsung dan tidak langsung antar variabel. Pengaruh langsung adalah pengaruh variabel eksogen terhadap endogen tanpa melalui variabel eksogen lainnya, sedangkan pengaruh tidak langsung adalah pengaruh variabel eksogen yang mempengaruhi variabel endogen melalui variabel lain yang disebut variabel moderator yang dikutip oleh Hanifah dkk, 2016. Pengujian kecocokan model dilakukan dengan cara membandingkan matriks korelasi teoretis dengan matriks korelasi empiris, jika kedua matriks identik maka model yang diajukan tersebut dapat diterima (Riduwan \& Kuncoro 2014:146). Uji kecocokan model dapat dilakukan dengan menentukan nilai Q sebagai berikut.

$Q=\frac{1-R_{m}^{2}}{1-M} \ldots \ldots$

Dengan

$\mathrm{R}_{\mathrm{m}}^{2}=1-\left(1-\mathrm{R}_{1}^{2}\right) \cdot\left(1-\mathrm{R}_{2}^{2}\right) \ldots \ldots\left(1-\mathrm{R}_{\mathrm{p}}^{2}\right)$.

$\mathrm{M}=\mathrm{R}_{\mathrm{m}}{ }^{2}$ setelah dilakukan model trimming

Apabila nilai $\mathrm{Q}=1$ mengindikasikan model fit sempurna. Jika $\mathrm{Q}<1$, untuk menentukan fit tidaknya model maka statistik 
koefisien $\mathrm{Q}$ perlu diuji dengan statistik $\mathrm{W}$ yang dihitung dengan rumus

$W$ hitung $=-(N-d) \ln Q \ldots \ldots$ (1)

Dengan:

$\mathrm{N}=$ ukuran sampel

$\mathrm{d}=$ Banyaknya koefisien jalur yang tidak signifikan sama dengan degree of freedom $=$ derajat bebas

$R_{m}^{2}=$ Koefisien determinasi multipel untuk model yang diusulkan

$\mathrm{M}=$ Koefisien determinan multipel $\left(R_{m}^{2}\right)$ setelah koefisien jalur yang tidak signifikan dihilangkan.

\section{Hasil Penelitian dan Pembahasan}

\section{Deskripsi Kebiasaan Membaca}

Kebiasaan membaca diukur melalui angket dengan 10 butir item pernyataan. Indikator kebiasaan membaca dalam penelitian ini yaitu: 1) keinginan untuk membaca; 2) objek bacaan yang disenangi; 3) jumlah bacaan yang dibaca; 4) durasi kegiatan membaca; dan 5) daya ingat. Data yang diperoleh dari angket yang disebarkan kepada 112 responden menunjukkan bahwa variabel kebiasaan membaca diperoleh skor tertinggi sebesar 40 dari skor tertinggi yang mungkin dicapai sebesar 40 (10x4), dan skor terendah sebesar 19 dari skor terendah yang mungkin dicapai sebesar 10 (10x1). Skor tersebut kemudian dianalisis dan diperoleh harga mean sebesar sebesar 30,88; median sebesar 31,00; modus sebesar 31, dan standar deviasi sebesar 4,419.

Berdasarkan perhitungan kelas interval, maka dapat disusun tabel distribusi frekuensi variabel kebiasaan membaca yang dapat ditunjukkan pada Tabel 2 sebagaimana berikut dibawah ini:

\begin{tabular}{ccc}
\multicolumn{2}{c}{ Tabel 2 } & Distribusi Frekuensi Variabel Kebiasaan Membaca \\
\hline No & Rentang Skor & Frekuensi \\
\hline 1 & $19-21$ & 4 \\
2 & $22-24$ & 6 \\
3 & $25-27$ & 19 \\
4 & $28-30$ & 24 \\
5 & $31-33$ & 28 \\
6 & $34-36$ & 18 \\
7 & $37-39$ & 11 \\
8 & $40-42$ & 12 \\
& Jumlah & 112 \\
\hline
\end{tabular}

Terdapat 31 siswa $(27,67 \%)$ yang memiliki kebiasaan membaca dalam kategori sangat tinggi, 35 siswa $(31,25 \%)$ memliki kebiasaan membaca dalam kategori tinggi, 31 siswa $(27,67 \%)$ memiliki kebiasaan membaca dalam kategori rendah, dan 15 siswa (13,39\%) memiliki kebiasaan membaca dalam kategori sangat rendah. Berdasarkan distribusi kecenderungan frekuensi variabel kebiasaan membaca diatas, dapat disajikan dalam pie chart seperti pada Gambar 1 berikut:

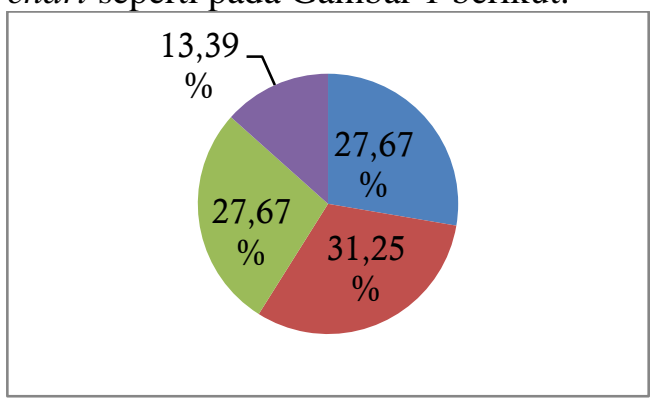

Gambar 1 Pie Chart Kecenderungan Kebiasaan Membaca

Berdasarkan data dari identifikasi kategori variabel kebiasaan membaca, menunjukkan bahwa kecenderungan variabel kebiasaan membaca dominan pada kategori tinggi, namun yang perlu diperhatikan adalah kebiasaan membaca dalam kategori rendah dan sangat rendah yang mencapai 46 siswa $(41,06 \%)$.

\section{Deskripsi Motivasi Belajar}

Data yang diperoleh dari angket yang disebarkan kepada 112 responden menunjukkan bahwa variabel motivasi belajar diperoleh skor tertinggi sebesar 40 dari skor tertinggi yang mungkin dicapai sebesar 40 (10x4), dan skor terendah 28 sebesar dari skor terendah yang mungkin dicapai sebesar 10 (10x1). Skor tersebut kemudian dianalisis dan diperoleh harga mean sebesar 35,54; median sebesar 35,00; modus sebesar 35, dan standar deviasi sebesar 2,278. Berdasarkan perhitungan kelas interval, maka dapat disusun tabel distribusi frekuensi variabel motivasi belajar seperti ditunjukkan pada Tabel 3 berikut:

\begin{tabular}{ccc}
\multicolumn{2}{c}{ Tabel 3 Distribusi Frekuensi Variabel Motivasi Belajar } \\
\hline No & Rentang Skor & Frekuensi \\
\hline 1 & $28-29$ & 1 \\
2 & $30-31$ & 5 \\
3 & $32-33$ & 13 \\
4 & $34-35$ & 38 \\
5 & $36-37$ & 29 \\
6 & $38-39$ & 24 \\
7 & $40-41$ & 2 \\
& Jumlah & 112 \\
\hline
\end{tabular}


Ada 12 siswa $(10,72 \%)$ yang memiliki motivasi belajar dalam kategori sangat tinggi, terdapat 83 siswa $(74,10 \%)$ memiliki motivasi belajar dalam kategori tinggi, terdapat 16 siswa $(14,28 \%)$ memiliki motivasi belajar dan terdapat 1 siswa $(0,89 \%)$ yang memiliki motivasi belajar dalam kategori rendah. Berdasarkan distribusi kecenderungan frekuensi variabel motivasi belajar diatas, dapat disajikan dalam pie chart seperti pada Gambar 2 berikut:

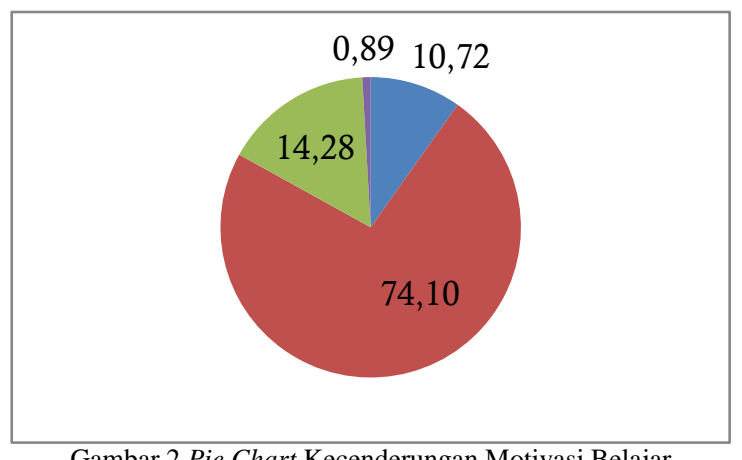

Gambar 2 Pie Chart Kecenderungan Motivasi Belajar

\section{Deskripsi Prestasi Belajar}

Data mengenai variabel prestasi belajar dalam penelitian ini diperoleh melalui dokumentasi Ujian Akhir Semester (UAS) dalam pelajaran IPA di kelas VII. Berdasarkan perhitungan kelas interval, maka dapat disusun tabel distribusi frekuensi variabel prestasi belajar seperti ditunjukkan pada Tabel 4 berikut

\begin{tabular}{ccc}
\multicolumn{2}{c}{ Tabel 4 Distribusi Frekuensi } & Variabel Prestasi Belajar \\
\hline No & Interval Kelas & Frekuensi \\
\hline 1 & $75-77$ & 46 \\
2 & $78-80$ & 51 \\
3 & $81-83$ & 12 \\
4 & $84-86$ & 1 \\
5 & $90-92$ & 1 \\
6 & $93-95$ & 1 \\
\hline & Jumlah & 112 \\
\hline
\end{tabular}

Berdasarkan data yang terkumpul diketahui skor tertinggi sebesar 91 dan skor terendah sebesar 75, selanjutnya dilakukan analisis dan diperoleh harga mean sebesar 78,21; median sebesar 78,00; modus sebesar 78, dan standar deviasi sebesar 2,939.

Identifikasi kecenderungan tinggi rendahnya prestasi belajar IPA dalam penelitian ini tidak menggunakan penentuan mean dan standar deviasi ideal, tetapi menggunakan nilai kriteria ketuntasan minimal (KKM) sesuai dengan aturan yang diberikan sekolah. Jika ketercapaian belajarnya $\geq 75$ maka siswa dapat dikatakan tuntas belajar atau kompeten, sebaiknya jika ketercapaiannya $<75$, maka dapat dikatakan siswa belum tuntas atau belum kompeten. Data yang diperoleh melalui identifikasi kategori variabel prestasi belajar, menunjukkan bahwa kecenderungan prestasi belajar pada kategori tuntas.

\section{Deskripsi Kemampuan Literasi Sains}

Variabel kemampuan literasi sains diukur melalui soal uraian dengan 9 butir item pertanyaan. Indikator kemampuan literasi sains dalam penelitian ini yaitu: 1) pengetahuan epistemik; 2) pengetahuan prosedural; dan 3) pengetahuan. Data yang diperoleh dari tes yang disebarkan kepada 112 responden menunjukkan bahwa variabel kemampuan literasi sains diperoleh skor tertinggi sebesar 65 dan skor terendah sebesar 27. Skor tersebut kemudian dianalisis dan diperoleh harga mean sebesar 43,83; median sebesar 44; modus sebesar 52, dan standar deviasi sebesar 8,638.

Berdasarkan perhitungan kelas interval, maka dapat disusun tabel distribusi frekuensi variabel kemampuan literasi sains seperti ditunjukkan pada Tabel 5 berikut:

Tabel 5 Distribusi Frekuensi Variabel Kemampuan Literasi

\begin{tabular}{|c|c|c|}
\hline \\
\hline No & Interval Kelas & Frekuensi \\
\hline 1 & $27-31$ & 4 \\
\hline 2 & $32-36$ & 23 \\
\hline 3 & $37-41$ & 18 \\
\hline 4 & $42-46$ & 21 \\
\hline 5 & $47-51$ & 18 \\
\hline 6 & $52-56$ & 23 \\
\hline 7 & $57-61$ & 4 \\
\hline \multicolumn{2}{|r|}{ Jumlah } & 112 \\
\hline
\end{tabular}

kemampuan literasi sains dalam kategori sangat tinggi, terdapat 19 siswa $(16,96 \%)$ memiliki kemampuan literasi sains dalam kategori tinggi, 23 siswa $(20,53 \%)$ memiliki kemampuan literasi sains dalam kategori rendah dan terdapat 42 siswa $(37,5 \%)$ memiliki kemampuan literasi sains dalam kategori sangat rendah. Berdasarkan distribusi kecenderungan frekuensi variabel kemampuan literasi sains diatas, dapat disajikan dalam pie chart seperti pada Gambar 3 berikut: 


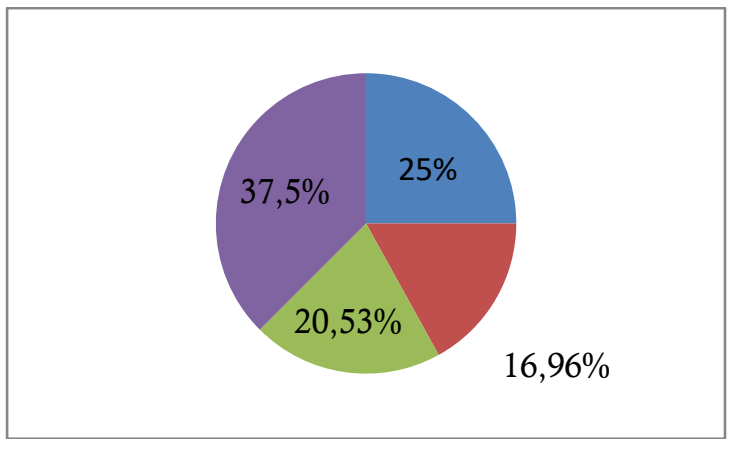

Gambar 3 Pie Chart Kecenderungan Kemampuan Literasi Sains

Berdasarkan data dari identifikasi kategori variabel kemampuan literasi sains, menunjukkan bahwa kecenderungan variabel kemampuan literasi sains pada kategori rendah dan sangat rendah $(58,03 \%)$.

\section{Pengaruh Langsung Kebiasaan Membaca Terhadap Motivasi Belajar}

Pengaruh langsung kebiasaan membaca terhadap motivasi belajar sebesar $0,16 \%$. Secara parsial kebiasan membaca dapat berpengaruh sebesar $2,1 \%$, namun mengalami penurunan karena adanya variabel-variabel lain yang tidak diteliti sehingga pengaruh langsung kebiasaan membaca terhadap motivasi belajar hanya sebesar $0,16 \%$. Hasil pemaparan berdasarkan penelitian tentang kemampuan literasi sains khususnya di SMP Negeri 2 Bua Ponrang yang telah dibiasakan membaca serta memiliki motivasi dan prestasi belajar yang baik. Siswa yang memiliki motivasi yang tinggi akan lebih maju dibanding siswa yang lain, motivasi belajar merupakan salah satu faktor kunci yang dapat membantu siswa dalam memahami bacaan serta membantu kinerja dan kualitas pemahaman seseorang terhadap bacaan. Kebiasaan membaca tidak akan tertanam dalam diri siswa manakala guru tidak mendorong siswa untuk mengekplorasi pengetahuan baru dengan sebanyak mungkin membaca ditambah lagi dengan kecanggihan teknologi yang semakin maju sehingga menyebabkan siswa tidak memiliki dorongan atau motivasi untuk membaca, dengan adanya motivasi untuk membaca dapat memicu motivasi belajar siswa.

\section{Pengaruh Langsung Kebiasaan Membaca terhadap Prestasi Belajar}

Kebiasaan membaca berpengaruh langsung terhadap prestasi belajar 9,67\% . Secara parsial $20,6 \%$. Terdapat perbedaan yang besar antara pengaruh langsung dan parsial mencapai 10,93\%. Hasil penelitian ini didukung oleh penelitian yang dilakukan oleh Gaona \& Gonzalez, 2011 menghasilkan adanya korelasi antara kebiasaan membaca dan prestasi akademik ditinjau dari beberapa indikator kebiasan membaca yang diteliti dalam penelitian ini yang sesuai dengan penelitian Gaona \& Gonzalez yaitu jumlah buku yang dibaca dan durasi kegiatan membaca, penelitian yang dilakukan Sainer, 2014 menyatakan bahwa ada hubungan antara kebiasaan membaca terhadap prestasi belajar, prestasi belajar dipengaruhi langsung oleh kebiasaan membaca seseorang (Owusu, 2014)

Untuk mencapai prestasi belajar yang baik diperlukan usaha, salah satunya adalah dengan senantiasa membiasakan membaca secara rutin. Wahyuningtyas dkk, 2012 menyatakan dengan membiasakan membaca yang baik, cenderung akan menghasilkan prestasi belajar yang baik.

Setiawati dkk, 2013 menyatakan materi bacaan yang baik akan memotivasi siswa untuk membaca dan belajar dengan sungguh-sungguh sehingga dapat menunjang pemahaman sebelumnya yang dimiliki oleh siswa.

\section{Pengaruh Langsung Motivasi Belajar terhadap Prestasi Belajar}

Pengaruh langsung variabel motivasi belajar terhadap sebesar $1,58 \%$. Secara parsial motivasi belajar dapat berpengaruh terhadap prestasi belajar hingga $16,3 \%$. Adanya pengaruh antara motivasi belajar dan prestasi belajar didukung oleh beberapa penelitian terdahulu yang telah dilakukan yaitu penelitian yang dilakukan oleh Patrick dkk, 2007 menyatakan motivasi belajar merupakan salah satu faktor yang mempengaruhi prestasi belajar, adanya hubungan yang signifikan antara motivasi belajar dengan prestasi belajar (Sainer, 2014), dan penelitian yang terbaru dilakukan oleh Ningrum \& Matondang, 2017 mengungkapkan hubungan yang positif antara motivasi belajar dengan prestasi belajar. Adanya pengaruh antara motivasi belajar 
dengan prestasi belajar didukung oleh teori yang dipaparkan oleh Slameto yang dikutip oleh Pakpahan, 2016 bahwa prestasi belajar dipengaruhi oleh faktor eksternal dan faktor internal. Faktor internal merupakan faktor pendorong yang berasal dari dalam siswa (motivasi belajar) dan faktor eksternal merupakan faktor yang bersumber dari diri luar diri siswa seperti faktor lingkungan, selain itu proses pembelajaran yang baik akan memberikan hasil yang baik terutama terhadap siswa, namun hasil yang baik tidak akan terwujud tanpa adanya motivasi atau dorongan yang berasal dari dalam diri siswa itu untuk mengikuti dan melaksanakan pembelajaran. Ndapaloka dkk, 2016 menyatakan pola pembelajaran yang baik akan memotivasi siswa untuk belajar yang akan berdampak pada peningkatan prestasi belajar. Siswa yang termotivasi tidak akan merasa terpaksa dan tertekan dalam mengikuti pembelajaran, sehingga senantiasa memacu dirinya untuk meningkatkan prestasi, kemampuan diri serta kreativitas yang dimiliki.

\section{Pengaruh Langsung Kebiasaan Membaca Terhadap Kemampuan Literasi Sains}

Kebiasaan membaca memberi pengaruh langsung sebesar 3,6\%. Secara parsial kebiasaan membaca memberi pengaruh sebesar 5,8\% terhadap kemampuan literasi sains. Hasil penelitian ini didukung oleh penelitian yang dilakukan oleh Turmo tahun 2004 yang menjadikan buku atau sumber bacaan sebagai salah satu faktor yang mempengaruhi kemampuan literasi sains remaja 15 tahun di Norwegia. Palpani, 2012 menyatakan kebiasaan membaca merupakan aspek penting yang dapat membentuk masyarakat yang literate di dunia, literate yang dimaksud salah satunya adalah kemampuan literasi sains. Buku menjadi salah satu faktor pendukung yang mempengaruhi kemampuan literasi yang dimiliki siswa di Indonesia dengan kata lain semakin sering seorang siswa membaca akan berpengaruh terhadap kemampuan literasi siswa tersebut (Pakpahan,2016)

\section{Pengaruh Langsung Motivasi Belajar terhadap Kemampuan Literasi Sains}

Motivasi belajar ternyata belum mampu memberikan pengaruh terhadap kemampuan literasi sains siswa. Secara teoritis motivasi belajar dapat memberikan pengaruh terhadap kemampuan literasi sains, hasill penelitian ini bertentangan dengan penelitian sebelumnya yang dilakukan oleh Bagiarta dkk, 2015 yang menyatakan motivasi berpengaruh terhadap literasi sains siswa. Tidak adanya pengaruh antara motivasi belajar terhadap kemampuan literasi sains dapat disebabkan karena instrumen motivasi belajar yang digunakan belum mampu mengungkap motivasi belajar yang dapat berpengaruh terhadap kemampuan literasi sains.

\section{Pengaruh Langsung Prestasi Belajar terhadap Kemampuan Literasi Sains}

Prestasi belajar berpengaruh langsung terhadap kemampuan literasi sains sebesar $7,12 \%$. Secara parsial prestasi belajar dapat berpengaruh terhadap kemampuan literasi sains hingga mencapai $75,2 \%$ namun kemungkinan masuknya variabel-variabel yang tidak diukur menyebabkan pengaruh langsung prestasi belajar terhadap kemampuan literasi sains turun menjadi $7,12 \%$. Hal tersebut menunjukkan bahwa variabel di luar prestasi belajar memberikan pengaruh yang cukup besar terhadap kemampuan literasi sains yaitu sebesar Berdasarkan hasil pemaparan di atas sehingga perlu untuk dilakukan penelitian tentang kemampuan literasi sains khususnya di SMP Negeri 2 Bua Ponrang yang telah dibiasakan membaca serta memiliki motivasi dan prestasi belajar yang baik.sains yang belum memenuhi skor kriteria ketuntasan minimal disebabkan karena siswa belum terbiasa mengerjakan soal-soal literasi sains.

\section{Pengaruh Tak Langsung Kebiasaan Membaca terhadap Prestasi Belajar}

Berdasarkan perhitungan didapatkan bahwa kebiasaan membaca berpengaruh sebesar $0,50 \%$ terhadap prestasi belajar melalui motivasi belajar. Persentase total kebiasaan membaca terhadap prestasi belajar melalui motivasi belajar sebesar $10,17 \%$. Persentase pengaruh tak langsung dan pengaruh total 
masih dipengaruhi oleh beberapa variable lain yang mungkin mempengaruhi.

Membaca bertujuan untuk memahami dan menangkap makna serta pesan yang terkandung di dalam sebuah bacaan sehingga dapat memacu daya nalar dan konsentrasi yang dimiliki seseorang, apabila membaca telah dilakukan sejak dini membaca dapat dijadikan sebagai salah satu media untuk menggali bakat dan potensi yang dimiliki siswa. Potensi inis dapat terlihat melalui prestasi yang diraih oleh siswa. Kebiasaan membaca memberikan pengaruh yang lebih besar dibandingkan motivasi belajar. Apabila terdapat dua siswa dengan motivasi belajar yang sama, namun salah satu siswa terbiasa membaca maka dimungkinkan siswa yang terbiasa membaca memiliki prestasi belajar lebih baik dibandingkan dengan yang lain.

\section{Pengaruh Tak Langsung Kebiasaan Membaca terhadap Kemampuan Literasi Sains}

Kebiasaan membaca berpengaruh secara tidak langung terhadap kemampuan literasi sains sebesar $0,13 \%$. Pengaruh total kebiasaan membaca terhadap kemampuan literasi sains melalui motivasi belajar adalah sebesar 3,73\%, lebih besar dibandingkan dengan pengaruh langsung kebiasaan membaca terhadap kemampuan literasi sains.

Pakpahan, 2016 menyatakan bahwa capaian literasi sains siswa peserta studi PISA merupakan hasil dari berbagai faktor yang saling terkait antara yang dipelajari di satuan pendidikan dan pengalamannya dalam kehidupan sehari-hari.

Hasil penelitian menunjukkan bahwa variabel yang memberikan pengaruh paling tinggi terhadap kemampuan literasi sains adalah kebiasaan membaca. Oleh karena itu kegiatan-kegiatan yang dapat mendukung kebiasaan membaca perlu ditingkatkan.

\section{Pengujian Kecocokan Model}

Pengujian kecocokan model diperlukan untuk menentukan apakah model hipotetik yang diajukan sudah sesuai (fit) atau konsisten dengan data empirik.
Nilai Q yang diperoleh dari hasil perhitungan $Q=$

$\frac{1-(1-0,002)(1-0,097)(1-0,072)}{1-(1-0,002)(1-0,097)(1-0,071)} \ldots . .(1)$
$Q=\frac{1-(0,998)(0,903)(0,928)}{1-(0,998)(0,903)(0,929)} \ldots \ldots .(2)$

$Q=\frac{1-0,8363}{1-0,8372} \ldots$

$Q=\frac{0,1637}{0,1628}=1,005 \ldots$ (4)

Pengujian model teoretis ditentukan dengan menentukan nilai $\mathrm{Q}$ dan $\mathrm{W}$ melalui uji statistic chi-square. Berdasarkan perhitungan didapatkan nilai $Q$ sebesar 1,005 yang mengindikasikan model fit sempurna sehingga tidak perlu dilanjutkan dengan uji statistik W.

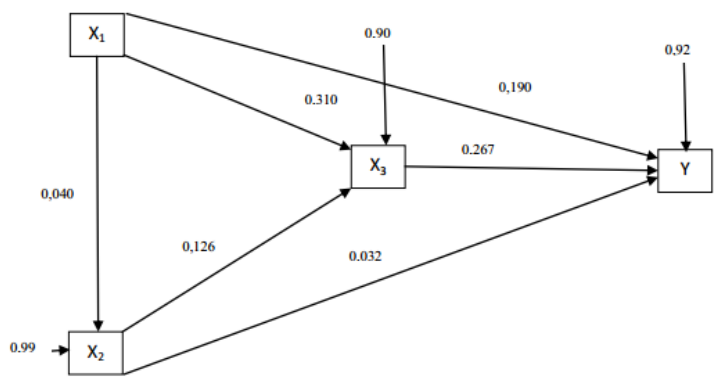

Gambar 4 Model Korelasi Teoritis Hubungan Variabel Kebiasaan Membaca, Motivasi Belajar dan Prestasi Belajar terhadap Kemampuan Literasi Sains

\section{Kesimpulan dan Rekomendasi}

Berdasarkan hasil analisis terhadap variabel kebiasaan membaca, motivasi belajar, prestasi belajar, dan literasi sains dapat ditarik kesimpulan bahwa kebiasaan membaca memberikan pengaruh yang paling besar terhadap kemampuan literasi sains baik secara langsung maupun tidak langsung. Kebiasaan membaca secara langsung berpengaruh sebesar $0,16 \%$ terhadap kemampuan motivasi belajar, secara tidak langsung berpengaruh sebesar $10,17 \%$ terhadap prestasi belajar dan $3,73 \%$ terhadap kemampuan literasi sains. Kemampuan literasi sains dapat dicapai dengan lebih baik apabila siswa dilatih dan dibiasakan untuk mengerjakan soal-soal literasi sains dan dibiasakan membaca sehingga siswa memiliki prestasi belajar yang baik yang didukung oleh motivasi belajar yang baik pula.

Berdasarkan hasil penelitian maka diajukan beberapa rekomendasi, yaitu : (1) Lebih memperbanyak pertanyaan untuk soal 
literasi sains dan siswa dibiasakan berlatih dengan soal-soal yang menguji dan mengasah kemampuan literasi sains; (2) Angket motivasi belajar perlu ditambah beberapa item pernyataan; (3) Penelitian dilakukan dalam lingkup yang lebih luas tidak berfokus pada satu sekolah ; (4) dilakukan penelitian yang berkaitan dengan literasi sains dengan variabel yang berbeda yang dimiliki agar kemampuan literasi sains siswa dapat meningkat dan semakin membaik.

\section{Daftar Pustaka}

Bagiarta, I.N., Karyasa, I.W., \& Suardana, I Nyoman. (2015). Komparasi Literasi Sains Antara Siswa Yang Dibelajarkan dengan Model Pembelajaran Kooperatif Tipe GI (Group Investigation) dan Model Pembelajaran Inkuiri Terbimbing (Guided Inquiry) Ditinjau Dari Motivasi Berprestasi Siswa SMP. E-Journal Program Pascasarjana Universitas Pendidikan Ganesha Program Studi Pendidikan IPA, V: 1-11

Gaona, J.C., Galicia., \& Gonzalez, E.R.V. (2011). Relationship Between Reading Habits, University Library and Academic Performance in A Sample of Psychology Students. Revista De La Educacion Superior, XL(1): 55-73

Hanifah, P.D., Marwoto, P., \& Sugianto. (2016). Pengaruh Kemampuan Kognitif, Kreastivitas, Dan Memecahkan Masalah Terhadap Sikap Ilmiah Siswa SD. Journal of Primary Education, 5(1): 10-20

Ndapaloka, V., Hardyanto, W., \& Prihatin, T. (2016). Pengaruh Supervisi Akademik Pengawas dan Kepemimpinan Kepala Sekolah Melalui Motivasi Berprestasi Sebagai Mediasi Terhadap Kinerja Guru SMK Negeri Kabupaten Ende. Educational Management, 5(1): 42-54

Ningrum, Sulistia \& Matondang, Saiful Anwar. (2017). The Correlation between Students Motivations and Achievement in Reading Comprehension. The International Journal of Social Sciences and Humanities Invention, 4(7): 3636-3639

Nuh, M. (2014). Aplikasi Pendekatan Saintifik Pada Kurikulum 2013 Berkontribusi Positif Terhadap Pengembangan Literasi Siswa Dalam Matematika dan IPA. https://www.academia.edu/9100714/Literasi Lintas Kurikulum (Diunduh 22 Oktober 2016)

Owusu-Acheaw, M. (2014). Reading Habits Among Students and its Effect on Academic
Performance: A Study of Students of Koforidua Polytechnic. Library Philosophy and Practice (E-journal). 1130. http://digitalcommons.unl.edu/libphilprac/1 130

Pakpahan, R. (2016). Faktor-Faktor yang Mempengaruhi Capaian Literasi Matematika Siswa Indonesia dalam PISA 2012. Jurnal Pendidikan dan Kebudayaan, 1(3). 331-347

Palpani, K.K. (2012). Promising Reading Habits an Creating Literate Social. International Reference Research Journal, III(2). 91

Patrick, A.O., Kpangban, E., \& Chibueeze, O.O. (2007). Motivation effects on test scores of senior secondary school science students. Study Home Community Science, 1(1), 5764.

Permanasari, A. (2014) . Kurikulum 2013 : Implikasinya Dalam Pembelajaran di Sekolah, Pendidikan Profesi dan Pendidikan Tinggi. Makalah. Seminar Nasional Pendidikan Karakter di Gedung SCC Palopo, Palopo. 03 Mei 2014.

Rafiqah, M., Yusmansyah, M.S. (2013). Pengaruh Motivasi Belajar Terhadap Prestasi Belajar. Alibkin, 02(2)

Riduwan \& Kuncoro, E.A. 2014. Cara Menggunakan dan Memakai Path Analysis (Analisis Jalur). Bandung. Alfabeta

Sainer, Mohammad. 2014. Hubungan Antara Motivasi Belajar dan Kebiasaan Membaca Siswa dengan Prestasi Belajar IPS pada Siswa Kelas V SD Negeri di Kecamatan Labuhan Ratu Bandar Lampung Tahun Ajaran 2013/2014. digilib unila.ac.id (diakses 30 September 2017)

Sandjojo, N. 2011. Metode Analisis Jalur (Path Analysis) dan Aplikasinya. Jakarta. Pustaka Sinar Harapan

Setiawati, I.K., Rusilowati, A., Khumaedi. (2013). Pembuatan Buku Cerita IPA Yang Mengintegrasikan Materi Kebencanaan Alam Untuk Meningkatkan Literasi Membaca dan Pembentukan Karakter. Jurnal Pendidikan IPA Indonesia, 2(2): 129135

Turmo, Are. (2004). Scientific Literacy and Socioeconomic Background among 15 Year Olds :A Nordic Perspective. Scandinavian Journal of Educational Research, 48(3):290-304

Wahyuningtyas, Neni., Sumarmi \& Suryantoro Agus. (2012). Hubungan Minat dan Kebiasaan Membaca dengan Prestasi Belajar Mahasiswa Pendidikan Geografi Universitas Negeri Malang. Tesis 